


\title{
Coups, "smart coups" and elections: Right power strategies in a context of Left hegemony
}

\author{
'Golpes, "golpes inteligentes" e eleições: \\ Estratégias de poder direitas num contexto \\ de hegemonia de esquerda'.
}

* Barry Cannon

\begin{abstract}
Most analyses of Right-wing power strategies in Latin America highlight the relative paucity of dedicated Right-wing political parties, and the preponderance of non-electoral strategies. Despite this such studies continue to privilege the electoral over other strategies. This paper presents a more wide-ranging, comprehensive perspective based on political sociology and political psychology theories. Here strategies are categorised at three levels - electoral, extraelectoral and semi- or extra-constitutional - which can be activated in a multi-layered manner, depending on the level of threat perceived to Right objectives and on conditions on the ground. Using the case study of the removal of Dilma Rousseff from the presidency in Brazil in 2016, the article seeks to illustrate the ultimate aim of achieving a "smart coup", whereby left governments are forced out of office with relatively little bloodshed and an element of popular and institutional legitimacy. In this way the Latin American Right aims to integrate electoral and non-electoral strategies to the democratic context of Left hegemony in the region.
\end{abstract}

\begin{abstract}
Resumo
A maioria das análises das estratégias de poder de direita na América Latina destacam a relativa escassez de partidos políticos de direita dedicados e a preponderância de estratégias não-eleitorais. Apesar disso, tais estudos continuam a privilegiar o eleitoral em detrimento de outras estratégias. Este artigo apresenta uma perspectiva mais abrangente baseada em sociologia política e teorias de psicologia política. Aqui, as estratégias são categorizadas em três níveis - eleitoral, extraeleitoral e semi- ou extra-constitucional - que pode ser ativado de várias maneiras, dependendo do nível de ameaça percebida aos objetivos do Direito e às condições no terreno. Além disso, em casos de grande ameaça, o ideal é conseguir um "golpe inteligente", pelo qual os governos de esquerda são forçados a sair do cargo com um elemento de legitimidade popular e institucional. Deste modo, a Direita LatinoAmericana tem como objetivo integrar as estratégias eleitorais e não-eleitorais ao contexto democrático da hegemonia de esquerda na região
\end{abstract}

Palavras-chave: América Latina, Direito, Ameaça, Estratégias, 'Golpes inteligentes.'

Keywords: Latin America, Right, Threat, Strategies, Smart Coups

\footnotetext{
* Barry Cannon é professor do Departamento de Sociologia da Universidade de Maynooth, na Irlanda. Seu livro mais recente é O Direito na América Latina: Poder das Elites, Hegemonia e Luta pelo Estado (Routledge, 2016) (em inglês)

E-mail: barry.cannon@nuim.ie
} 


\section{Introduction}

What and who are the Latin American Right, and what is their role in and impact on politics in the region? In this article I argue that traditional political science accounts of the phenomenon, with their emphasis on political parties and institutions, fail to grasp the multi-faceted nature of the Right in the region, with its context of vertiginous inequality. Instead I offer a more complex, layered and comprehensive view of the Latin American Right, composed of the following elements.

First, I identify, following Bobbio (1996), the central role of inequality, particularly class inequalities, in Left/Right differentiation. Second, I advance Michael Mann's concept of social power as an alternative framework, with its focus on power networks in the economic, ideological, political, military and transnational arenas. Third, I illustrate the key position of neoliberalism in Latin American Right discourse and policy. Moreover, I argue that the ultimate aim of such ideological preferences is to form what I call right-oriented state/society complexes, in which neoliberal forms of governance are embedded into Latin American power structures at the national, regional and transnational level. Ultimately, the "full spectrum" stability of such governance makes it much more difficult for ideological alternatives to prosper, as it is supported not just by state actors, but those at the sub-state and supra-state level too.

Fourth, I also argue that the success of this project has been fundamentally threatened by post-neoliberal,' 'pink tide' governments in each of the power networks, provoking a multi-level strategic response from the Right. This has three interlinked and complementary levels: the institutional, taking in parties, elections and institutions; mobilisational, involving not only popular mobilisations, but also elite 'structural' and 'instrumental' power (Fairfield 2015) especially in the economy and in the media, respectively; and, semi- or extra-constitutional, building on the previous strategies but aimed at a more immediate removal of a sitting Left president. I offer Brazil as a case study to illustrate the operation of these strategies. Overall I argue that the Latin American Right is a multi-faceted phenomenon, which reacts to the threat of the Left to elite interests, and presents a wide variety of strategic responses to this threat, with an ultimate aim to embed neoliberal governance at the national, regional and transnational levels. In this way, the analysis, unlike many previously, incorporates actors at levels above and below the state, as well as at the level of the state itself in a more systematic fashion.

\section{The Right in theory}

How can we define the Left/Right cleavage? First, following Bobbio (1996), issues of inequality are essential to its definition, both over time and across space; policy solutions may change but this central concern is constant. Second, this concern with inequality also has profound class consequences: policies associated with the Left 
can involve more state intervention to lessen inequalities, while those on the Right seek to lessen state intervention with regard to inequalities, but to increase it with regard to ensuring market dominance. Each policy option has implicit and explicit outcomes favouring some classes over others, and hence class and, in particular, the role of elites should be central to any discussion of the Right. Third, such debates do not remain within State boundaries, but also structure international and global policy making, giving such debates an important transnational aspect (Noel and Thérien 2008; Silva 2009). Finally, the Left/Right debate takes place within a wider and neverending struggle for hegemony between these fundamental worldviews. While certain consensuses may emerge at particular times, these are rarely fixed and can and will be challenged.

In light of this discussion the core meaning of the Left/Right distinction can be conceived as "whether one supports or opposes social change in an egalitarian direction" (Ronald Inglehart cited in Noël and Thérien 2008, 10). As neoliberalism is recognised by many as leading to increased socio-economic inequality (Harvey 2005; Stiglitz 2012; Piketty, 2014), it can be argued that those who support and actively promote neoliberalism are on the Right of the political spectrum while those who oppose them, or at least question them, are to the Left. There is also, it must be noted, an important social conservative aspect to Right wing discourse which itself has an anti-egalitarian thrust. Yet this rarely disturbs, and often complements, the centrality of neoliberalism to the Right's overall project. The Right then, in the current historical context, is a class-based, elite-led project with neoliberalism as its ideological core.

\section{The Right in Latin America}

Chalmers et al. (1992) briefly trace the history of the Right in $20^{\text {th }}$ century Latin America and note that political parties were not prominent in its political expressions throughout that century. During the Import Substitution Industrialisation (ISI) period, from the 1930's to the 1960's, many segments of the Right had 'personal, bureaucratic, and clientelistic ties' to state power (Chalmers et al.1992,4) which obviated the need for Right political parties in most of the region. However, these national-populist regimes betrayed their rightist allies, by supporting and encouraging 'populist, participative corporatism' (Chalmers et al.1992, 4) which threatened elite dominance in favour of popular sectors, particularly as the global crises of the Keynesian model and its Latin American, ISI equivalent began to take hold.

As O' Donnell (1978) shows, the sense of threat felt by elites in the face of popular empowerment in the ISI period, led the former groups to turn to the military for support in the 1970s and early 1980s, drawing together an 'alliance of technocrats, the military and state-linked businesses' (Chalmers et al. 1992, 4) to rule the state through 'bureaucratic authoritarianism' (O' Donnell 1978). This arrangement, however, turned out to be spectacularly unsuccessful, at least in political terms, for a number of reasons, 
including the unreliability of the military as an ally, especially due to the many human rights abuses committed by them during this period and, above all, the end of the Cold War and the eventual disappearance of the threat of the revolutionary Left. Therefore, as the 1980s progressed, sectors of the Right began to embrace democracy and indeed played a 'crucial role, if not dominated, transitions to democracy' in this period (Chalmers et al. 1992, 3). This position also allowed the Right to redefine democracy in the liberal sense of competitive democratic institutions, while the equalising, substantive elements of democracy were muted (Chalmers et al. 1992, 5). Right-wing sectors loosened their previous close ties to the state, in favour of a new emphasis on parties, legislatures and elections (Chalmers et al. 1992, 7), and a separation between state, society and church. The aim, then, was to create a Lockean 'night-watchman state' although this was not always achieved in practice (Chalmers et al. 1992, 9).

The Latin American Right then goes far beyond political parties in this account. Traditionally the authors maintain, the main actors on the Right were Church hierarchies, the military and socio-economic elites (Chalmers et al. 1992, 7), and as neoliberalism develops there is an increasing role for the private media, and 'large firms and powerful think tanks' (Boron 1992,69) with a distancing between the military and the state. The new 'core constituency' then of the Latin American Right - that is 'those actors of society that are most important to its political agenda and resources' (Gibson 1992, 15) - are those groups who support the free market and a lessening of state power over market relations.

Therefore, it is not political parties which dominate the Right in Latin America, but rather the paramount expressions of economic (business groups), ideological (Church, media, think tanks etc.), and military power. It is these which condition political power, without negating the possibility that political power can also shape and condition these areas of power in turn. In effect, there is no hierarchy between these different sectors of power; indeed, if anything elites seek harmony between all four of them in favour of the supremacy of their own social power. The problem for the Right then is not how to transform the traditional relationships between these areas of power and the State'into institutionalised and responsible representation' as Chalmers et al. (1992, 4) maintain, but rather how this can be done without allowing elite domination in all four areas to be threatened. Hence, the aim is achieving stable regimes of governance, which nonetheless, do not threaten, but rather enhance elite dominance and the liberal economic and political models which they support.

Yet, this broader vision of the Latin American Right, in this and most other treatments of the subject matter (Middlebrook 2000; Luna and Rovira Kaltwasser 2014) is muted in favour of an analytical accent which remains invariably on the subsidiarity of these other areas of power to state power. Indeed, often they are not recognised as distinct areas of power in their own right, but rather as simply sectional interests which jostle for recognition with other such interests, such as labour, to have access to state power. Yet this underestimates the overwhelming weight of elite dominance in 
these areas of power and its ability to override political power and reorient it to an elite worldview. The literature on the Latin American Right then is dominated by a liberal, institutionalist, pluralist perspective, which is insufficiently equipped to analyse the complexities which the vertiginous asymmetries of power present in the region. The issue of power then should be central to any analysis, as these elites possess greater social power than any other group in Latin American societies.

\section{Mann, Social Power and the Latin American Right}

Here I contend that Michael Mann's concept of social power provides a broader framework from which to view these different arenas. For Mann, power operates through 'multiple overlapping and intersecting sociospatial networks' (Mann, 1986, 13), within a specifically identified territory. These networks of power reflect the four sources of social power in any given social formation - ideological, economic, military, and political -none of which has primacy as and of itself, but which can develop such primacy at distinct moments in history in different societies, depending on the context found.

Mann defines each power network as Weberian 'ideal types' with their particular organisational forms. Ideological power then is 'when meaning, norms and aesthetic and ritual practices are monopolized by a distinctive group [which must be] highly plausible in the conditions of the time' (Mann 1986, 23). Economic power'derives from the satisfaction of subsistence needs through the social organisation of the extraction, transformation, distribution, and consumption of the objects of nature' (Mann 1986, 23). This process causes the formation of social classes, with the dominant class monopolising control over these processes (Mann 1986, 23). Military power 'derives from the necessity of organised physical defence and its usefulness for aggression' (Mann 1986, 26). Ideally, in democracies, military power should be subservient to political power, but this is not always the case as Latin America's history of military regimes amply demonstrates.

Political power 'derives from the usefulness of centralised, institutionalised, territorialised regulation on many aspects of social relations' in other words 'state power' (Mann 1986, 23). Political power can take despotic or infrastructural forms, the first when elites 'take decisions without negotiation with groups in civil society' (Mann, 2002, 2); the second when states 'possess infrastructures penetrating universally throughout civil society, through which political elites can extract resources from, and provide services to all its subjects' (Mann, 2002, 2). In most advanced democracies, state power is despotically weak but infrastructurally strong, that is that states have high levels of command over each network of power, but that this command rests on equally high levels of popular legitimacy, usually achieved through political parties. It also has a strong transnational element, usually organised along imperial or multistate lines (Mann, 1986, 27). As Silva (2009) points out, this factor has important 
consequences for Latin America in particular due to the region's high dependence on international financial institutions, foreign investment, international markets and the influence of the United States.

The central issue for Latin American states to develop democratically then is, according to Mann (2002), the lessening of inequalities, which in turn requires the reduction of oligarchical power with an increase in state power. Yet, here I argue that Latin American elites possess sufficient collective power across each of the four power networks to successfully resist any move towards greater social equalisation, which would by necessity involve a lessening of their own power. Moreover, Fairfield (2015) shows that neoliberalism has increased rather than lessened the business elite's structural and instrumental power, using it to reinforce that ideology, both nationally and transnationally, across each of the power networks. Hence, neoliberalism is central to the maintenance and extension of elite power in the current historical conjuncture, a fact recognised both in Right-wing discourse and in Right-wing policy performance.

\section{Right-Wing Neoliberal Discourses and Practice in Latin America}

Cannon (2016) finds that among Right or liberal-leaning civil society groups and political parties in four countries in South America - Argentina, Chile, Colombia and Venezuela - there is a still firm adherence to neoliberal market-based principles with, however, a more nuanced appreciation for the need for poverty alleviation. In terms of state/market relations there is a firm consensus around the subsidiarity of the state to the market. State intervention in the economy - and indeed society - must be kept to a minimum, if it should exist at all; indeed the state should regard the economy as the preserve of the private sector and ensure its continuance. Basic public services primarily health and education - should be provided for the poor, but these services do not necessarily need to be provided by the state. Nor is the aim to lessen socioeconomic inequality, but rather to facilitate individual participation in the market, with employment, in the private sector preferably, seen as the main goal. This viewpoint hence is in line with orthodox neoliberal policies as promulgated by international financial institutions such as the IMF and the World Bank, as well as mainstream political thinking in Europe and the United States (Silva 2009, 39).

Views on inequalities of class, race or gender are for the most part unacknowledged by subjects in all four countries, with instead an emphasis on the individual, who with the right guidance, support and personal effort and regardless of race, class or gender, can participate in national life and achieve success to any level. Women may 'choose' not to participate in the market in order to devote time to family, and this is sometimes ascribed to her essential nature, as innately caring and nurturing and not simply to her individual choice. It is to be noted, however, that such gender stereotypes are not generalised as in Argentina and Chile, in particular, there is a general acceptance 
on the need for action to improve gender equality in the workplace. Nevertheless, policy solutions offered are primarily market based, voluntary and rarely accept state intervention. Meanwhile, education, especially in Argentina, is identified as key to ensure that a supposed innate entrepreneurialism predominates in the popular imagination.

Hence, despite some differences around levels of state provision, discourse among Right-leaning and liberal actors, in politics, civil society and in business, across these four countries reflects a remarkably coherent view of the type of society required in Latin America; one based on neoliberal, market-based tenets in which resulting inequalities are of scant concern. These findings are similar to those found by Reis (2011) in her study of Brazilian elite attitudes on the same issues, providing further evidence of their prevalence among elites in the region.

Furthermore, on examining policy options in four Latin American countries which are most dominated by neoliberalism in the current context - Chile, Colombia, Mexico and Peru - we find such beliefs transformed faithfully into policy. Despite Left-led governments in two of these countries (at the time of writing Chile and Peru), neoliberalism is so deeply embedded in national power networks that alternative policy options are extremely difficult to implement without fierce elite resistance. Economically, these countries are characterised by little state controlled enterprise and low levels of market controlling state intervention, and with high levels of market freedom, corporatisation and transnationalisation of business ownership structures. They also have highly open trading regimes, with a large number of free trade agreements (FTAs), most commonly with the US. FTA's are particularly important as they usually contain legal clauses which inhibit policy change liable to prejudice profit, regardless of its social or environmental benefits. Equally importantly, these rules are usually governed by courts outside national jurisdictions, often in the United States.

Ideological regimes are controlled through highly concentrated and oligopolized media ownership structures which show heavy editorial biases in favour of maintaining and deepening the neoliberal status quo. Moreover, networks of liberal and right-wing think tanks, supporting and espousing neoliberal tenets, are found in each of these countries often established with financial support from transnational organisations. Political regimes show remarkable levels of ideological uniformity in favour of neoliberalism, and even when this is not the case, policy deviance from neoliberal tenets is highly controlled due to the embeddedness of neoliberalism in the other power networks. Militarily these regimes usually maintain alliances with the United States, cooperating with that country in the region, and sometimes, beyond, including facilitating US intervention under the banners of the so-called wars "on drugs" and "on terror". As can be seen by this account, high levels of transnational influence traverse most of these power networks, mostly from the US but also from Europe, and increasingly from China. Moreover, the official establishment in 2012 of the transnational organisation Pacific Alliance (PA), grouping these neoliberalised 
states together, with Costa Rica and Panama as future candidates for membership, suggests a longer term transnational project with the potential to homogenise this political economy model throughout the Latin American region.

In each of these countries then neoliberalism has formidable collective power in the sense that neoliberal advocates have horizontal linkages across all of the power clusters examined here. The confluence of interests around neoliberalism between elites in each of these power clusters result in a narrowing of space for ideological alternatives to gain traction. Confluences of interests can also aggregate around social conservatism and law-and-order issues, but neoliberalism will usually be privileged. As stated, organisations such as the Pacific Alliance aims to further embed this model at the transnational level, linking it up to the key centres of neoliberalism in North America and Europe and then across to the economies of East Asia, as well as projecting itself as an alternative to existing regional groupings such as ALBA and Mercosur. Furthermore, with the accession of Chile to the OECD and with Colombia also on its way to becoming a member, such agreements will make it even more difficult to deviate from neoliberal tenets and opens up the possibility for their extension across the region. These regimes I therefore suggest are right-oriented state/society complexes due to the deep embeddedness of neoliberal governance at the sub-state, state and supra-state levels. This makes it extremely difficult for non-neoliberal alternatives to prosper, even if such alternatives appear, as was the case, for example, in Peru under Ollanta Humala (2011-2016) (Adrianzén 2014).

Hence on a discourse and on a practice level, in the current historical context neoliberalism remains the main ideological project among the Right in many countries in the region, with a view to its eventual dominance throughout. Nevertheless, these tenets have been powerfully challenged since the beginning of the millennium, by post-neoliberal regimes seeking to control the excesses of the market and bring new forms of political participation into action.

\section{Right-wing prospects in Left-led Latin America}

The Latin American region, and particularly South America, has been affected by the "pink tide" of Left-wing governments which swept through the region from the millennium onwards, presenting a considerable challenge to Right-wing, neoliberal hegemony. In four countries - Argentina, Bolivia, Ecuador and, above all, Venezuela Right hegemony has been challenged to an important degree in each of Mann's five power clusters, with each government introducing unorthodox policies contradicting important neoliberal tenets around free markets and/or liberal democracy. Yet this challenge has also been felt in a number of other countries, especially in the regional powerhouse Brazil where there is evidence of a shift in hegemony in each of the five areas, although not to the same intensity as in the above-mentioned states. 
Economically, it could be argued that the threat to Right-wing hegemony was at three levels in the region during the apogee of the 'pink tide'. In the Bolivarian countries of Venezuela, Bolivia, Ecuador, and also in Argentina under Nestor Kirchner and then his wife Cristina (2003-2015), it can be assessed as from medium to high. These countries are the only countries in the region with significant reversals of privatisation as well as introducing other measures which control, intervene in, or contradict the freedom of the market, including exchange controls (Venezuela, Argentina), interfering with the "autonomy" of the Central Bank, price controls, debt defaults (Argentina, Ecuador) and land-redistribution (Bolivia, Venezuela) among others (Flores-Macias 2010, 415-6). Even in the so-called "social democratic" Left-led countries of Brazil and Uruguay, privatisation has been stalled, and in Brazil state intervention in the economy remained high during the first presidency of the PT's Dilma Rousseff (2010-2014). Hence while the greatest threat to the neoliberal project during the "pink tide" era is posed by Venezuela, followed by the other Bolivarian countries of Ecuador and Bolivia, there were also medium level threats in Argentina and even a low to medium threat in PT-led Brazil.

Similar findings are evident when one looks at the other power networks examined here. In the political arena, for example, the Bolivarian countries particularly have been distancing themselves from liberal representative models towards more participative ones. These were accompanied by strengthened executives, reduced checks and balances and restrictions on civil and political liberties creating a climate of 'class-based polarisation over the very meaning of democracy' (Smilde 2014, 29). In terms of ideological power, many Left governments strengthened state broadcasters, including at the regional level with the launch of Telesur, a type of Al Jazeera for the Latin American and Caribbean (LAC) region. A variety of laws have been introduced by the three Bolivarian governments, and Argentina, to attempt to limit concentration of ownership and increasing control on content. Community ownership of media has been especially encouraged in Venezuela, but also in Bolivia and to a lesser extent in Argentina. While there are questions over the effectiveness of these measures in terms of increased democratisation of the media (Doleac, 2015) the moves are sufficient to set off alarm bells among elites who most benefit from the existing ownership structures.

Militarily, there are profound differences between the Bolivarian countries, other Left-led countries and neoliberalised countries, with the latter participating enthusiastically in US-led military initiatives, while the Bolivarian countries reduce or eliminate such cooperation and those in the middle remain neutral (Bitar 2013, 3435). And in terms of transnational power, Left-led countries have embarked on new regional initiatives such as UNASUR, CELAC or ALBA, as opposed to the US dominated OAS (Organisation of American States) and the regional, neoliberalised Pacific Alliance. In all these ways then, the Left has posed serious challenges to Right-elite hegemony in many countries in the region, disturbing preceding attempts to establish stable 
structures of neoliberal governance, not just at the national level, but also at regional and hemispheric levels too. Right-wing elites, however, have not taken this situation lying down, and instead have developed multi-level strategies seeking the removal of the threat posed by these governments.

\section{Right-wing strategies in Left-led Latin America}

Three levels of Right strategy can be identified in response to this situation of disturbed neoliberal hegemony by Left-led governments in the region: institutional, mobilisational, and semi- or extra-constitutional. The first strategy is largely contained within existing institutionality in the form of party and electoral activity; in the second, this can be complimented by popular demonstrations, investor strikes, media campaigns and a wide variety of mobilisational activities beyond the political power network and into all other networks including the transnational; and, in the third, semior extra-constitutional level strategic activity can be further extended to include the removal of the government, including with Armed Forces involvement but preferably in using semi-constitutional methods to ensure a smooth transition to a new Rightoriented government, in what I call 'smart coups.' These strategies, however, are not necessarily exclusive but rather can be complementary, emerging from the particular conjunctural dynamic. Their success is linked not just to the perception of threat felt by elites but also by the level of vulnerability of the democratic polity existing in a specific state. The higher the level of threat felt by elites and the higher the vulnerability of the polity, the more likely coups - 'smart' or otherwise - will occur, and even be successful. Overall, I suggest that this theoretical approach is more complete than previous, more traditional political science approaches, as it provides greater flexibility across time and space and greater comprehensiveness in its inclusion of a wider number of actors in a more systematised fashion.

\section{Institutional Strategies}

In terms of institutional strategies, this first of all refers to the building of institutionalised parties. Luna and Rovira Kaltwassser (2011) find two types of Right political parties in the region. The first type, with emblematic examples such as the UDI (Unión Democráta Independiente/Independent Democrat Union) in Chile, are well organised, with a strong central hierarchy which nonetheless allows for decentralised territorial organisation and hence distinct types of electoral mobilisation. These parties can capture a combined popular support from both upper and lower social sectors, with frequent use of clientelism to support this. The second type of parties they identify, giving examples of the " $U$ " party of ex-president Álvaro Uribe in Colombia and RN (Renovación Nacional/National Renovation) in Chile, are territorially centralised almost exclusively in the capital, with vertical decision-making structures. Election campaigns 
are strongly centred on the candidate as a solution to a specific problem, such as Uribe's "democratic security" position in Colombia as an answer to that country's civil war. While many of the parties in both camps have differing historical backgrounds all 'have a privileged link with business sectors, which coincides with their free-market positions' (Luna and Rovira Kaltwassser 2011, 17).

Further strategies are the ideological colonisation of parties which have been historically Left, Left-populist, Social Democratic, Christian Democratic and indeed conservative in their ideological orientation. Some examples are AD (Acción Democrática/Democratic Action) in Venezuela, the MNR (Movimiento Nacionalista Revolucionario/Revolutionary Nationalist Movement) in Bolivia, Carlos Menem's Peronist Party in Argentina, the PRI (Partido Revolucionario Institucional/Institutional Revolutionary Party) in Mexico, and the Liberal Party in Colombia. The result of this has been the steady decline of the existing party structure in most countries in the region.

Finally, the use of democratic institutions to discredit sitting Left politicians is also a favoured strategy, thereby creating conditions of crisis which can favour the removal of a Left leader. Here Right-politicians which dominate such institutions blame institutional crises on Left leaders, rather than on the very institutions which the former dominate. In tandem elites use their considerable structural and instrumental power, particularly in the media, to amplify such charges. An emblematic example was the removal through impeachment proceedings of Dilma Rousseff in 2016, which is explored in more detail below.

\section{Mobilisational Strategies}

Mobilisational strategies involve a variety of activities beyond institutionalised, party based politics which nevertheless aim to install opposition parties and presidents in institutionalised power. Instances of such strategic manoeuvres against Left governments have been experienced in a wide variety of countries in the region, including Argentina, Brazil, Bolivia, and Venezuela. In Argentina, the socalled paro agrario in 2008 was a particularly tense moment for the government of Cristina Fernández de Kirchner. Beginning in March that year, agricultural producers revolted against a new tax on exports of agricultural produce being introduced by the government, with regular demonstrations and supply shortages. It quickly escalated into one of the greatest challenges against her government from the Right, leading eventually to the latter's triumph, led by Mauricio Macri, in the 2015 elections. Similar tactics, including violence, took place in the rich, gas producing eastern provinces of Bolivia between 2006-2009, aimed here at secession, and at destabilisation of the Left government of Evo Morales. Finally, in Venezuela student-led demonstrations continued throughout the latter-part of the Chávez presidency (1999-2013) and right up into the subsequent administration led by Nicolás Maduro (2013-). These tactic were also used against President Dilma Rousseff in Brazil (see below). In most of 
these cases we can see evidence of an activation of oligarchical power in many of the networks identified here, including economic, ideological and transnational.

Key features of these mobilisational strategies are, first, that they are led by elites as opposed to poorer groups, although the latter may become involved. Second, a wide variety of activity is used, from mass demonstrations, to more direct actions such as road blockades, production strikes etc. Third, they are almost always accompanied by comprehensive private media campaigns in support of the demonstrators. Fourth, in Bolivia and Venezuela in particular, US support, moral, strategic and financial was provided. Fifth, in almost all cases the ultimate aim was the removal of the government, except in Bolivia where the aim was secessionist, which if it had succeeded would have resulted in destabilisation of the government. It is important to note nevertheless, that these strategies did not result in the abandonment of electoral strategies and other institutional strategies, but rather accompanied them.

\section{Semi- or Extra-Constitutional Strategies}

The cases of Venezuela (2002), Honduras (2009), Paraguay (2012) and Brazil (2016), with a further possible but disputed case in Ecuador (2010), demonstrate clearly that coups, be they with or without military involvement, are possible in the current context, and as the Honduran (see Cannon and Hume, 2012), Paraguayan (see Lambert, 2012) and Brazilian (see below) cases illustrate, can succeed if national and international contextual circumstances are right. Most of these examples share a number of key characteristics. First, they build on previous institutional and mobilisational strategies, providing a multi-layered, dynamic, relational, and varied strategic approach. These involved demonstrations of some sort (with the exception of Paraguay); media campaigns in all cases against the sitting Left president; US and allied government support (again with the partial exception of Paraguay, at least with regard to the US) with mostly solid regional rejection of the coup; attempts at providing a veneer of institutionality to the removal of the government (except Ecuador and with the most successful example being Paraguay and Brazil); and, the direct involvement of all or some elements of the Armed Forces (with the exception of Brazil and partial exception of Paraguay).

Second, in all cases the aim was to reverse or stall any modifications to the economy and institutionality effected by the sitting Left government, that is a return to threatened models of elite-dominated polyarchy and market freedoms. Third, in each case almost all the power networks were involved: economic interests, often landed; ideological, especially the media; political, not just opposition political parties, but also state institutions; military, even in the case of Paraguay, although not so overtly; and transnational, most notably the United States, but also conservative governments in other parts of the West, such as Canada, Spain, Germany and the United Kingdom. These cases then are multi-layered strategies, involving sub-state, state, regional and 
supra-national agents, working in close cooperation to achieve a mutually agreed goal - the removal of an elected, Left leader.

\section{Brazil: A Case Study}

A good example of all three of these strategies being put into action, is that of the eventual ousting of Brazil's PT President Dilma Rousseff in August, 2016. As noted previously Brazil under the Workers' Party stalled privatisation and increased state intervention in the economy, especially under Rousseff's first presidential term (201015). Brazil also led efforts to increase Latin American, particularly South American, autonomy from US dominated regional fora, most notably through UNASUR, and forged an independent foreign policy, with its involvement in the BRICS, its support of Venezuela and its relations with Iran among other features. In this way Brazil presented a low- to medium-level threat to the neoliberal project. Furthermore, it was a very successful threat, with high levels of economic growth for most of the PT period, and a dramatic lowering of poverty and even inequality.

Yet the recession beginning in 2013 presented an opportunity for Right elites to restore their total dominance of the State, using the considerable structural power available to it both inside and outside Brazil's institutions. This process began over a two-month period in June-July, 2013, on the eve of the Confederations Cup, with the country seeing the largest popular mobilisations since its return to democracy in 1985. Started by a small, left grouping protesting modestly against public transport fare rises in Sao Paulo and Rio de Janeiro, these rapidly escalated into mass events, encompassing a whole range of issues and groups and drawing crowds of a million or more in the grand avenues of Sao Paulo. Initially the demonstrations were dismissed by right politicians and the right-wing corporatist media, with Gerardo Alckmin, right-wing PSDB governor of Sao Paulo state, branding demonstrators "vandals" and "troublemakers", and right-wing journalists labelling them "terrorists" (Conde and Jazeel, 2013: 441).

Yet this attitude changed dramatically as military police brutally attacked demonstrators, injuring a number of journalists in the process, and the right-wing media sensed a perfect opportunity to attack the PT-led federal government (Conde and Jazeel, 2013: 442; Sader, 2013; Saad-Filho, 2013: 659). From thence on they offered blanket coverage of the protests, emptying these of their radical content and framing them as against the more generic "state inefficiency and corruption" (Saad-Filho, 2013: 659). Participation in the marches exploded, with some marches in July reaching over one million people (ibid.). According to Winters and Witz-Shapiro (2014: 138) by this stage all Brazil was aware of the marches, with only 3 per cent in polls NOT having heard of them.

Moreover, the themes of the original marches became subsumed in a cacophony of demands, from same-sex marriage to the return of the military government. Most 
Ideological colonisation of emerging parties can also be observed in the Brazilian cases. In the 2014 elections, for example, there was a rush on the part of elites to endorse Socialist Party candidate Marina Silva in her challenge to Rousseff. Silva enjoyed considerable support among Brazil's highly oligopolized private media, and each time she surged in the polls, corresponding surges were felt in the Brazilian stock exchange, suggesting endorsement from the country's financial and business elite, despite her strong background in environmental politics (Grandin, 2014). Once Silva lost in the first round, however, elites support swiftly moved to Aécio Neves, the PSDB challenger.

The Right's gamble almost paid off in the elections, with Rousseff barely winning against Neves by a mere 3,28 per cent of the vote and the PT losing seats in Congress. This, however, emboldened the same sectors to organise more demonstrations in 2015 with similar demands attended by a similar demographic, in which calls for Rousseff's impeachment began to be heard and even for the return of the military government (Jimenez-Barca, 2016). Instrumental in the genesis of these protests were the corruption scandals involving the giant, mostly state-owned oil company Petrobras, providing kickbacks to politicians in return for favours, brought to light by a judicial enquiry known as Lavajato. While the media and elites project these scandals as being entirely the responsibility of Rousseff, despite her not having been accused of any crime, many of the accused are from the Right, including the Speakers of the Chamber of Deputies, Eduardo Cunha, and the Senate, Renan Calheiros, both from the PMDB; the chief opposition leader, and Rousseff's presidential challenger in the 2014 elections, Aécio Neves, of the PSDB; and, Michel Temer, the then vice-president also of the PMDB (Saad-Filho, 2015). Of these only Cunha has lost his position, after having served his purpose as the spearhead of the process which led to Rousseff's impeachment.

Temer, of course, ultimately replaced Dilma Rousseff as president on 31 August, 2016, despite the accusations of corruption against him, in a process similar to a "smart coup" as previously executed in Paraguay against President Lugo in 2012. After a tortuous and highly questioned impeachment process the Senate convicted Rousseff of using the pedalada, a commonly used accounting technique to temporarily reduce the deficit, despite a Senate committee previously declaring that this was not an impeachable offence (See Declerq, 2016 and Watts, 2016). While some suggested that this act was in order to stall the Lavajato process (see Miranda, 2016), it also became clear that a key objective was not just to restore neoliberalism but to embed it more deeply in Brazil's governance structures. Hence not only did Temer, on assuming the presidency, immediately announce standard neoliberal policies such as a firesale privatisation of state assets, including possibly parts of Petrobras, the State-owned oil giant (Robinson, 2016) and areas of the defence industry (Adghirni, 2016), as well as cuts in public spending on social programmes, and increased autonomy for the Central Bank (Leahy and Pearson, 2016), he also introduced a new law to set constitutional limits 
on spending for the next twenty years (Robinson, 2016). This law will institutionalise austerity for the foreseeable future, eliminate the minimum allocation for education and health, reducing access for the poor to these social goods, and tie the hands of any future government to increase social spending. In this way neoliberalism becomes imbricated in the Brazilian state structure more deeply, making it even more of a rightoriented state/society complex than ever before.

Hence in Brazil we can observe a good example of a combined, multi-layered elite-Right strategy, using electoral, mobilisational and semi-constitutional tactics to remove a sitting Left leader. Right elite forces did not abandon electoral institutional politics; indeed, these were used to the full in attempts to remove Rousseff. However, mobilisation tactics were also used, with the mainstream media and business sectors playing a central role in promoting mass demonstrations aimed ultimately at her removal, despite her "extraordinary moderation" (Saad-Filho, 2013: 662). Furthermore, this move was reinforced by a conservative institutionality, with little sympathy for closer popular participation in decision-making processes. This capitalised on popular discontent whipped up by the conservative media, engineering an impeachment process against Rousseff, which while regarding constitutional form, rested on a charge which was recognised even by a Senate committee as a legally dubious basis for impeachment proceedings. On this basis alone it can be considered an example of a 'smart coup', but one which nonetheless would not have been possible without executing the other levels of strategy identified here.

This removal was made possible, I would argue, for two reasons. First, it was due to the perception of threat felt by these elites to the continued presence of a PT-led administration, which despite tacking to the right during the first year of Rousseff's second term was nonetheless unpredictable and reluctant to deepen the neoliberal project. The second reason it was possible was due to a highly vulnerable polity in Brazil, as identified by Mares (2014: 94-95), with a high preference to non-democratic solutions to problems, a low assessment of the sitting government and a high regard for the military. Hence the combination of a united elite against the Rousseff government alongside a weak polity made the 'smart coup' against Rousseff possible and perhaps inevitable.

\section{Conclusion: A New Right for a New Millennium?}

To sum up, in this article I argue the following with regard to the Right in Latin America. First, the Right in the region is shaped and controlled by the sources of social power to an extraordinary degree. These sources of social power - economic, ideological, political, military and transnational - are in the present conjuncture, dominated by neoliberalism, both at a discursive and at a policy level, reducing space for alternative policy constellations to emerge. The main aim of this new regional Right is to install at a national and transnational level, systems of neoliberal governance 
which cannot be unravelled by possible Left alternatives without great difficulty, if at all. Such systems of neoliberal governance I have termed right-oriented state/society complexes due to their totalising nature across the power spectrum.

Nevertheless, the "pink tide" governments which emerged since the millennium, particularly those grouped under the Bolivarian label, organised transnationally into the ALBA grouping, have reversed elite social power in many of these power networks to a sufficient degree to alarm elites, suggesting a direct link between Right strategies and the intensity of change to the neoliberal model effected by Left governments in the region. Here I suggest, that the higher the level of such change, the higher the level of threat felt by elites to the neoliberal model, with the opposite also being true.

Right counter-acting strategies can vary in intensity and widen in terms of actors and activity in response to the level of perceived threat. I identify three levels of strategy: institutional, mobilisational, and extra-constitutional. In the first, this is largely contained within existing institutionality in the form of party and electoral activity, and the use of state institutions for partisan goals; in the second, this can be complemented by popular demonstrations, investor strikes, media campaigns and a wide variety of mobilisational activities beyond the political power network and into all other networks including the transnational; and, in the third, semi- or extraconstitutional level strategic activity can be further extended to include the removal of the government, including with Armed Forces involvement (extra-constitutional) but preferably in such a way as to ensure a smooth transition to a new Right-oriented government, in what I have called "smart coups" or semi-constitutional removals. I further argue that these strategies are not exclusive but can be complementary, emerging from the particular conjunctural dynamic.

Moreover, I tentatively suggest that the success of these strategies can be directly linked not just to the perception of threat felt by elites but also by the level of vulnerability of the democratic polity existing in a specific state. The higher the level of threat felt by elites and the higher the vulnerability of the polity, the more likely coups will occur, and even be successful. Overall, I suggest that this theoretical approach is more complete than previous, more traditional, political science approaches, as it provides greater flexibility across time and space and greater comprehensiveness in its inclusion of a wider number of actors in a more systematised fashion. I offer the recent removal of the PT administration led by Dilma Rousseff as a case study of such strategies being used successfully.

Grugel and Riggirozzi (2012), Wylde (2012) and others have argued that postneoliberal forms of governance have emerged - tentative and experimental - which have sought to challenge neoliberal governance and reassert the role of the state in reinforcing popular citizenship, both in the economic and at the political levels. I suggest here that the Right has risen to defeat this challenge by seeking the return of neoliberal systems of governance, but this time made more secure through actual or mooted insertion into dense regional (PA) transnational (FTAs, OECD) and 
inter-continental governance structures (TISA and TTIP), to ensure that such challenges, if they emerge again, are thoroughly neutered from the outset. We can see evidence of this in the rapid implementation of neoliberal measures by the newly installed Macri administration in Argentina (Kozameh, 2016; Adair, 2016) and by the "interim government" of Michel Temer in Brazil (Ituassa and Badia i Dalmases,2016; Rocha, 2016). Right strategies then are multi-scalar in their approach involving nonstate, state, regional and transnational actors to achieve neoliberalised governance structure which are dominated by these same actors. 


\section{Bibliography}

ADAIR, J., 'Argentina Turns North'. Available: http://nacla.org/news/2016/03/30/argentina-turnsnorth, 30 March, 2016. Accessed: June, 7th, 2016.

ADRIANZÉN, C. A. 'Una obra para varios elencos: Apuntes sobre la estabilidad del neoliberalismo en el Perú', Nueva Sociedad 254, November-December, 2014.

BITAR, S. E., 'QUASI-BASES: The US military and Domestic Politics in Latin America'. Unpublished manuscript. Available: http://web.isanet.org/Web/Conferences/FLACSO-ISA\%20 BuenosAires\%202014/Archive/33fec7f3-b805-4fff-b7ea-c9f6fe48e1db.pdf, 2016.. Accessed: 15/06/2015, 34-35.

BORON, A.,'Becoming Democrats? Some sceptical considerations on the Right in South America', in Chalmers, D. A., M. do Carmo Campello de Souza, A. A. Boron, (eds.). The Right and Democracy in Latin America, New York: Praeger, 1992.

CANNON, B., The Right in Latin America: Elite Power, Hegemony and the Struggle for the State. New York and London: Routledge, 2016.

CANNON, B., and HUME, M. (2012) Central America, civil society and the'pink tide': democratization or de-democratization? Democratization, 19(6), pp. 1039-1064.(doi:10.1080/13510347.20 11.619775)

CHALMERS, D. A., M. DO CARMO CAMPELLO DE SOUZA, A. A. BORON, 'Introduction: The Right and Latin American Democracies', in Chalmers, D. A., M. do Carmo Campello de Souza, A. A. Boron, (eds.). The Right and Democracy in Latin America, New York: Praeger..

CONDE, M., and TARIQ JAZEEL, 2013. 'Kicking Off in Brazil: Manifesting Democracy'. Journal of Latin American Cultural Studies: Travesia. 22 (4), pp. 437-450, 441.

DOLEAC, C. 'Insufficient Media Reforms in Latin America: Urgency to Go Further', Council on Hemispheric Affairs, www.coha.org/insufficient-media-reforms-in-latin-america-urgency-to-gofurther/, (accessed on 17 August, 2015), 19 February, 2015.

FAIRFIELD, T.,'Structural power in comparative political economy: perspectives from policy formulation in Latin America', Business and Politics, Vol 17, No 3 http://eprints.lse.ac.uk/62123/. (accessed on 11 August, 2015), 2015.

FLORES-MACÍAS, G. A., 'Statist vs. Pro-Market: Explaining Left Governments' Economic Policies in Latin America', Comparative Politics Vol 42, No 4, 2010.

GIBSON, E. L.,'Conservative Electoral Movements and Democratic Politics: Core Constituencies, Coalition Building, and the South American Electoral Right', in Chalmers, D. A., M. do Carmo Campello de Souza, A. A. Boron, (eds.). The Right and Democracy in Latin America, New York: Praeger, 1992.

GRANDIN, G.',Why Brazil's Elections Matter'. The Nation. http://www.thenation.com/ blog/181868/why-brazils-elections-matter, (accessed on 15 June, 2015), October, 6, 2014.

GRUGEL, J. and RIGGIROZZI, P.,'Post-neoliberalism in Latin America: Rebuilding and Reclaiming the State after Crisis'. Development and Change, Vol 43, No 1, 2012.

HARVEY, D., A Brief History of Neoliberalism. Oxford: Oxford University Press, 2005.

ITUASSU, A., and F. BADIA I DALMASES, 2016. A New Right has appeared on the Brazilian Political Spectrum., Available: https://www.opendemocracy.net/democraciaabierta/arthur-ituassufrancesc-badia-i-dalmases/new-right-has-appeared-in-brazilian-polit. Accessed: 7 June, 2016.

JIMENEZ BARCA, A., 2015. 'La oposición brasileña maniobra para ponerse al frente de la protesta social'. El País, 18 March. Available: http://internacional.elpais.com/internacional/2015/03/17/ actualidad/1426620385_776859.html. Accessed: 16/06/2015. 
KOZAMEH, S., 'Argentina's Painful Return to Economic Orthodoxy'. Available: https://nacla.org/ news/2016/02/08/argentina\%E2\%80\%99s-painful-return-\%E2\%80\%9Ceconomic-orthodoxy\%E2\%80\%9D-0, 8 February, 2016. Accessed: 7 June, 2016.

LAMBERT, P., 'The Lightening Impeachment of Paraguay's President Lugo', http://www.e-ir. info/2012/08/09/the-lightning-impeachment-of-paraguays-president-lugo/ (accessed: 16 July, 2015), E-International Relations, August, 9, 2012.

LUNA, J.P and C. ROVIRA KALTWASSER, 'Las derechas gobernantes en América Latina: hacia una caracterización preliminar', LASAForum, Vol XLII: No 3, Summer, 2011.

LUNA, J.P and C. ROVIRA KALTWASSER, (eds.) The Resilience of the Latin American Right. Baltimore: John Hopkins University Press, 2014.

MANN, M.,. The Sources of Social Power: Volume 1, A History of Power from the Beginning to AD 1760, Cambridge: Cambridge University Press, 1986.

MANN, M., 'The Crisis of the Latin American State', paper presented at the University of the Andes, Bogotá, Colombia, to the Conference "The Political Crisis and Internal Conflict in Colombia", , http://www.sscnet.ucla.edu/soc/faculty/mann/colombia.pdf, (accessed 10 June, 2015), April 10-13, 2002.

MARES, D. R., 2014. 'Citizen Security, Democracy and the Civil-Military Relationship' in Mares, D. (ed.), 2014. Debating Civil Military Relations in Latin America. Chicago IL.: Sussex Academic Press, pp. 81-100.

MIDDLEBROOK, K. J. (ed.). Conservative Parties, the Right, and Democracy in Latin America Baltimore: Johns Hopkins University Press, 2000.

MIRANDA, D., 'Globo's billionaire heir Joāo Roberto Marinho attacked me in the Guardian. Here's my response', (Accessed, 9 May, 2016), 15 April, 2016.

NÖEL, A. and J.P.THÉRIEN, Left and Right in Global Politics. Cambridge: Cambridge University Press, 2008.

O' DONNELL, G., 'Reflections on the Patterns of Change in the Bureaucratic-Authoritarian State', in South. American. Research Review, Vol 13 No 1, 1978.

PIKETTY, T., Capital in the Twenty-First Century. Harvard University Press, 2014.

REIS, E. P., 'Elite Perceptions of Poverty and Inequality in Brazil'. In Blofield, M, (ed.) The Great Gap: Inequality and the Politics of Redistribution in Latin America Pennsylvania: Pennsylvania State University Press, 2011.

ROCHA, J., 'Brazil prepares to roll back green laws'. Available: https://www.opendemocracy.net/ democraciaabierta/jan-rocha/brazil-prepares-to-roll-back-green-laws. 23 May, 2016. Accessed: 7 June, 2016,

SAAD-FILHO, A., 2013. 'Mass Protests under 'Left Neoliberalism': Brazil, June-July, 2013'. Critical Sociology, 39 (5), 657-669.

SADER, E., 2013. 'First Reflections on the mass movement that has shaken Brazil', Links: International Journal of Socialist Renewal. June, 22. Available: http://links.org.au/node/3402. Accessed: $16 / 05 / 2015$

SILVA, E., Challenging Neoliberalism in Latin America. Cambridge: Cambridge University Press, 2009.

SMILDE, D., 'From Partial to Full Conflict Theory: a Neo-Weberian Perspective on Post-Neoliberal Venezuela'. Unpublished manuscript. https://www.sas.upenn.edu/dcc/sites/www.sas.upenn. edu.dcc/files/uploads/Smilde\%20-\%20From\%20Partial\%20to\%20Full\%20Conflict\%20Theory. pdf, (accessed 11 June, 2015). November 2014. 
STIGLITZ, J., The Price of Inequality: How today's divided societies endanger our future New York: W.W. Norton \& Co., 2012.

WATTS, J.,'Dilma Rousseff: Brazilian Congress votes to impeach President'. The Guardian http:// www.theguardian.com/world/2016/apr/18/dilma-rousseff-congress-impeach-brazilian-president (Accessed on 11 May, 2016), 18 April, 2016.

WINTERS, M. S., and REBECCA WEITZ-SHAPIRO (2014), Partisan Protesters and Nonpartisan Protests in Brazil, in: Journal of Politics in Latin America, 6 (1), 137-150

WYLDE, C., Latin America after Neoliberalism: Development Regimes in Post-Crisis States? Houndmills, HANTS: Palgrave, 2012.

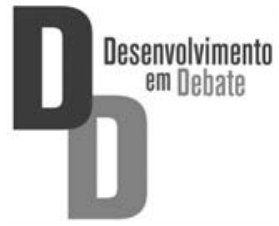

